\title{
An adolescent patient presenting with hyponatremic seizure: Questions
}

\author{
Meral Torun Bayram ${ }^{1} \cdot$ Gizem Yıldız $^{1} \cdot$ Alper Soylu $^{1}$ (D) $\cdot$ Salih Kavukçu ${ }^{1}$
}

Received: 28 January 2019 / Revised: 30 January 2019 / Accepted: 8 February 2019 / Published online: 6 March 2019

(C) IPNA 2019

Keywords Seizure $\cdot$ Hyponatremia $\cdot$ Child

\section{Case report}

A previously healthy 15 -year-old girl was referred to our clinic by a local hospital because of persistent unconsciousness following a generalized tonic-clonic seizure. Physical examination revealed an unconscious, well-developed adolescent with normal axillary temperature, pulse rate, and blood pressure. She was neither edematous nor dehydrated. There was no cranial nerve deficit, focal neurologic sign, papilledema, or neck stiffness. The only pathologic finding was the presence of a few dental caries. Cranial computed tomography, ordered after blood samples were obtained and IV line established, was normal.

Laboratory investigations revealed a serum sodium of $118 \mathrm{mmol} / \mathrm{L}$, potassium $3.73 \mathrm{mmol} / \mathrm{L}$, chloride $89 \mathrm{mmol} / \mathrm{L}$, bicarbonate $22 \mathrm{mmol} / \mathrm{L}$, blood urea nitrogen $4.3 \mathrm{mg} / \mathrm{dL}$, creatinine $0.36 \mathrm{mg} / \mathrm{dL}$, glucose $98 \mathrm{mg} / \mathrm{dL}$, calcium $9.01 \mathrm{mg} / \mathrm{dL}$, creatinine kinase $376 \mathrm{U} / \mathrm{L}, \mathrm{C}$-reactive protein (CRP) $0.5 \mathrm{mg} / \mathrm{L}$, and serum osmolality $240 \mathrm{mosmol} / \mathrm{kg}$. Urine osmolality was $325 \mathrm{mosmol} / \mathrm{kg}$, sodium $35 \mathrm{mmol} / \mathrm{L}$, and creatinine $7.01 \mathrm{mg} /$ $\mathrm{dL}$, giving a fractional excretion of sodium (FENa) of $1.5 \%$. Toxicologic analysis of urine was negative. Evaluation of cerebrospinal fluid was normal.

Hypertonic saline infusion $(6 \mathrm{~mL} / \mathrm{kg} 3 \% \mathrm{NaCl})$ was started to correct hyponatremia. In addition, parenteral ceftriaxone and acyclovir treatment were initiated. Her consciousness improved rapidly along with serum sodium level which was $129 \mathrm{mmol} / \mathrm{L}$ after $3 \mathrm{~h}$. Thereafter, hypertonic saline infusion was stopped and isotonic saline at a dose of maintenance fluid requirement was given. During follow-up, the patient was noted to be polyuric and serum sodium normalized within this period $(134 \mathrm{mmol} / \mathrm{L}$ after $10 \mathrm{~h}$ and $139 \mathrm{mmol} / \mathrm{L}$ after $14 \mathrm{~h})$. Along with improved serum sodium, her clinical condition also improved. Antimicrobial treatment was stopped when the culture results were reported to be sterile.

The parents stated that the patient had a toothache due to abscess formation for the last 3 days and used amoxicillinclavulonic acid plus etodolac during this period. When the patient regained consciousness, detailed questioning revealed the cause of hyponatremia.

\section{Question}

What is the cause of hyponatremia in this patient?

\section{Compliance with ethical standards}

Conflict of interest The authors declare that they have no conflict of interest.

Publisher's note Springer Nature remains neutral with regard to jurisdictional claims in published maps and institutional affiliations.

The answer to this question can be found at https://doi.org/10.1007/ s00467-019-04214-w.

\section{Alper Soylu}

alper.soylu@deu.edu.tr

1 Department of Pediatric Nephrology, Dokuz Eylül University

Medical Faculty, 35340 Balçova, İmir, Turkey 